\title{
Modeling Air Dispersion of Pollutants Emitted from the Daura Oil Refinery, Baghdad- Iraq using the CALPUFF Modeling System
}

\author{
R. M. Shubbar ${ }^{1}$, D. I. Lee ${ }^{2}$, H. A. Gzar ${ }^{3}$, and A. S. Rood $^{4}$ \\ ${ }^{1}$ Department of Automation and Control Systems, Midland Refineries Company, Baghdad 10016, Iraq \\ ${ }^{2}$ Department of Environmental Atmospheric Sciences, Pukyong National University, Busan 48513, Korea \\ ${ }^{3}$ Department of Civil Engineering, College of Engineering, Wasit University, Wasit 52001, Iraq \\ ${ }^{4} \mathrm{~K}$-Spar Inc. Scientific Consulting, Idaho Falls, Idaho 83402, USA
}

Received 28 May 2019; revised 09 August 2019; accepted 30 August 2019; published online 30 September 2019

\begin{abstract}
The CALPUFF atmospheric transport model was used to estimate ambient air concentrations of $\mathrm{SO}_{2}, \mathrm{CO}_{2} \mathrm{NO}_{2}$, and $\mathrm{PM}_{2.5}$, in a $256 \mathrm{~km}^{2}$ region surrounding the Daura oil refinery in Baghdad, Iraq during a six-month period in the summer for 2013 and the winter of 2014. The CALPUFF modeling system includes a meteorological processor (CALMET), a Lagrangian puff atmospheric transport model (CALPUFF), and a post processor (CALPOST). Source term and meteorological data, including surface and upper air observations, were pre-processed and formatted for CALMET and CALPUFF using FORTRAN programs. Monthly emission rates and stack parameters for twelve stack sources were included in the model. Winds out of the northwest predominated, followed by winds out of the north and the west. The urban regions with the highest pollutant concentrations in the study domain were the Daura Express Highway located south and southeast of the facility, and the refinery employee residences located west of the facility. These areas were closest to the Daura oil refinery. Predicted pollutant concentrations showed that $\mathrm{SO}_{2}$ and $\mathrm{CO}$ were higher than $\mathrm{NO}_{2}$ and $\mathrm{PM}_{2.5}$, for the study period because emission rates of $\mathrm{SO}_{2}$ and $\mathrm{CO}$ were greater than $\mathrm{NO}_{2}$ and $\mathrm{PM}_{2.5}$. Monthly dispersion patterns were similar among the pollutants and exhibit plumes in the predominant wind direction. Winter generally had the highest predicted pollutant concentrations compared to the summer months.
\end{abstract}

Keywords: Daura refinery, CALPUFF, pollutant, dispersion, CALMET

\section{Introduction}

Combustion sources are a primary source of atmospheric pollutants (Wark and Warner, 1976). Atmospheric emissions from industrial facilities such as oil refineries remain one of the largest environmental problems in many countries around the world. These industrial facilities emit large amounts of criteria pollutants that include sulfur dioxide $\left(\mathrm{SO}_{2}\right)$, carbon monoxide $(\mathrm{CO})$, nitric oxides $\left(\mathrm{NO}_{\mathrm{x}}\right)$, and particulate matter $(\mathrm{PM})$.

The transport of pollutants in the atmosphere is a result of three processes; advection transports pollutants in the mean wind direction, turbulent diffusion (dispersion) spreads the pollutant along the transport path, and molecular diffusion spreads pollutants in the absence of advection (Wark and Warner, 1976). These factors depend on the mean wind velocity, atmospheric stability including inversions conditions, and the influence of topography. Higher wind speeds result in greater dilution of pollutants in air and lower pollutant concentrations. Atmospheric instability results in greater turbulent diffusion, and thus greater plume spreading resulting in lower pollutant

${ }^{*}$ Corresponding author. Tel.: +9 647701714994 .

E-mail address: ramizmahdi@gmail.com (R. M. Shubbar).

ISSN: 2663-6859 print/2663-6867 online

(C) 2019 ISEIS All rights reserved. doi:10.3808/jeil.201900014 concentrations (Ahrens, 2007).

Previous researchers have investigated the emission and dispersion of pollutants from oil refinery operations in the region using atmospheric transport models. (Abdul-Wahab et al. 2002) analyzed air dispersion of $\mathrm{SO}_{2}$ emissions using the Industrial Source Complex Short Term (ISCST) model at the Mina al Fahal refinery in Oman. Gzar and Kseer (2009) investigated atmospheric emissions and dispersion of pollutants $(\mathrm{HC}$, $\mathrm{CO}, \mathrm{NO}_{\mathrm{x}}$, and $\mathrm{PM}$ ) under variable meteorological conditions, from three South Gas Company plants in Al-Basrah in Iraq using a Gaussian Plume model. Mehdizadeh and Rifai (2004) used two atmospheric transport models, Screening Air Dispersion Model (SCREEN) and ISCST, to assess the significance of individual point sources at on concentrations at high latitudes.

The CALPUFF (CALifornia PUFF) model (Scire et al., 2000) was used in this work to investigate the atmospheric dispersion of the criteria pollutants $\mathrm{SO}_{2}, \mathrm{CO}, \mathrm{NO}_{2}$, and $\mathrm{PM} 2.5$, in areas adjacent to Daura oil refinery, which located in the center of Baghdad, Iraq. Numerous studies have used CALPUFF to estimate atmospheric pollutants concentrations from emission sources. Levy et al. (2002) used CALPUFF to model the primary and secondary Particulate Matter (PM) concentrations related with emissions from industrial area in Illinois USA. Elbir 
(2003) estimated atmospheric concentrations from $\mathrm{SO}_{2}$ emissions using CALPUFF at Izmir in Turkey, Oshan et al. 2006 investigated pollutant concentrations in an urban area in Ohio, USA, he showed that CALPUFF's results were similar to those produced by the AERMOD (American Meteorological Society Environmental Protection Agency Regulatory Model) for the urban area studied. Dresser and Huizer (2011) compared predicted pollutant concentration from CALPUFF and AERMOD, and concluded the performance of CALPUFF was better than AERMOD in the near field $(<50 \mathrm{~km})$. Jeong $(2011)$ used CALPUFF and AERMOD to evaluate the dispersion of odors emitted from an industrial area in the Seobu industrial complex in Korea. He concluded that the CALPUFF predicted concentrations better matched observations than those of AERMOD did for average downwind odor concentrations.

Rood (2014) compared predicted tracer concentrations from four atmospheric dispersion models including CALPUFF, AERMOD, and ISC 2 with observed tracer concentrations taken at two concentric sampling rings 8 and $16 \mathrm{~km}$ from the release point. Rood (2014) concluded that the CALPUFF model exhibited the smallest variance, highest correlation, and highest number of predictions within a factor of two compared to the steady state models (AERMOD and ISC2).

Air pollution is one of the largest environmental problems in Baghdad, Iraq. The Daura refinery facility emits large amounts of pollutants to the ambient air. The annual average emission rates of $\mathrm{SO}_{2}, \mathrm{CO}, \mathrm{NO}_{2}$, and $\mathrm{PM}_{2.5}$ were 35189.1, $31077.5,3078.5$, and 831.4 ton/year respectively for the period from March 2013 to February 2014. Thus, gaseous pollutant and particulate matter is an environmental health concern to the workers in Daura refinery and people who live in the surrounding area.

To the best of our knowledge, this is the first application of CALPUFF modeling in Iraq for the four pollutants of concern $\left(\mathrm{SO}_{2}, \mathrm{CO}, \mathrm{NO}_{2}\right.$, and $\left.\mathrm{PM}_{2.5}\right)$. Emission rates of the pollutants calculated for twelve emission points over a period of six months. These twelve emission points represent the combined emissions from 30 plants, and 35 stacks using monthly average fuel consumption at Daura production units. We simulated monthly-average pollutant concentrations and identified the regions with the highest pollutant concentrations in urban areas within the city of Baghdad. In addition, we also investigated seasonal (i.e., summer and winter) variability of pollutant concentrations.

The organization of this paper is as follow. Background information, data, and study methods presented in Section 2, followed by a description of the CALPUFF model in Section 3. The results of this work showed in Section 4, and Section 5 provided a summary and the main conclusions.

\section{Background Information, Data and Study Methods}

A general description for Daura oil refinery, geographic and climatic conditions of the Baghdad region provided first, followed by the methods used in source term development and atmospheric modeling introduced in this section.

\subsection{Description of Daura Oil Refinery Area}

Daura oil refinery represents the main refinery of the MRC (Midland Refineries Company) in Iraq. It is located on the western side of Tigris River, about $4 \mathrm{~km}$ south of the center of Baghdad. The city of Baghdad is located in about the center of Iraq (Figure 1) and situated in generally flat terrain.

Daura refinery typically operates 24 hours per day and processes large amounts of crude oil that is refined into various petroleum products. It is one of the largest sources of air pollution in Baghdad metropolitan area. The Daura refinery includes twelve units comprising thirty processing plants. In the present work, these units considered as twelve individual point sources because minimal distance separates individual processing plants and some plants share the same stack.

Urban areas comprising buildings and palm trees situated around the refinery, along with a small factory for liquid gas filling. The Al-Imam Al-Hassan quarters are located east of the facility, and the Al-Jamaia quarter is located west and southwest of the facility. The employee residence compound lies on the western edge of the Daura refinery. The palm tree lined Daura express highway runs along the south and southeast side of the facility and eventually crosses the Tigris River east of the facility. A flat undeveloped region occupies the north side of the facility and extends to the southern bank of the Tigris River. Directly north of the Tigris River from this undeveloped area is the densely populated Al-Karada district.

The climate approximately of Baghdad Iraq characterized by hot, dry summers and cool, wet winters. Winds are predominately from north to northwest (Shubbar et al. 2016). The average daily high temperature in the winter is $16{ }^{\circ} \mathrm{C}$ and the average daily low in the winter is $2^{\circ} \mathrm{C}$. Summer temperatures often reach over $43{ }^{\circ} \mathrm{C}$ during July and August (Zakaria et al., 2013).

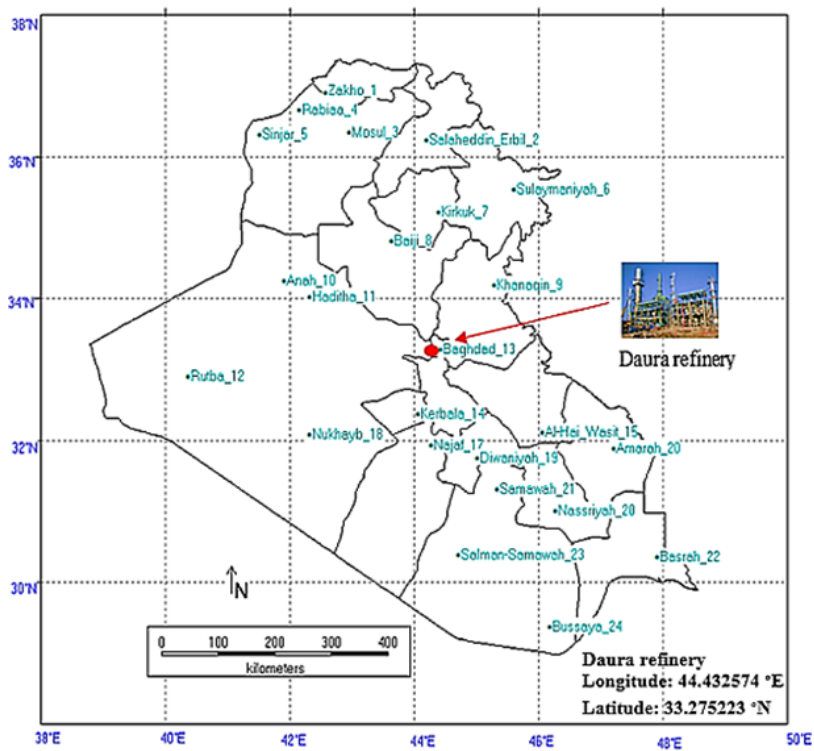

Figure 1. Geographic map shows main cities in Iraq, and the red circle represents the location of Daura oil refinery in Baghdad city. 
Table 1. Characteristics of the Point Sources in Daura Refinery

\begin{tabular}{|c|c|c|c|c|c|c|}
\hline \multirow[t]{2}{*}{ Point source } & \multirow[t]{2}{*}{ Number of stacks } & \multirow[t]{2}{*}{ Stack height $(\mathrm{m})$} & \multirow{2}{*}{$\begin{array}{l}\text { Stack diameter } \\
(\mathrm{m})\end{array}$} & \multirow{2}{*}{$\begin{array}{l}\text { Stack gas exit temp. } \\
(\mathrm{K})\end{array}$} & \multicolumn{2}{|c|}{ UTM coordinates $(\mathrm{km})$} \\
\hline & & & & & East & North \\
\hline CDU_1 & 1 & 46 & 2.4 & 640 & 446.641 & 3682.470 \\
\hline CDU_2 & 1 & 46 & 2.7 & 612 & 446.467 & 3682.386 \\
\hline CR_1 & 4 & 30 & 1 & 643 & 446.531 & 3682.305 \\
\hline $\mathrm{KH}$ & 2 & 20 & 1 & 593 & 446.560 & 3682.415 \\
\hline CR_2 & 5 & 30 & 1.5 & 548 & 446.770 & 3682.507 \\
\hline DCU_1_3 & 3 & 30 & 2 & 573 & 446.581 & 3682.240 \\
\hline PU_1 & 4 & 30 & 2 & 673 & 446.695 & 3682.143 \\
\hline PU_3 & 1 & 36 & 2.5 & 493 & 446.910 & 3681.871 \\
\hline LO_1 & 3 & 30 & 1 & 573 & 447.027 & 3681.711 \\
\hline LO_2 & 5 & 30 & 1 & 673 & 447.285 & 3681.583 \\
\hline LO_3 & 5 & 30 & 1 & 623 & 447.665 & 3681.581 \\
\hline PU_2 & 1 & 30 & 3 & 673 & 447.669 & 3681.362 \\
\hline
\end{tabular}

Table 2. Domain Modeling Conditions

\begin{tabular}{lll}
\hline $\begin{array}{l}\text { Grid origin (reference point defining domain location) in UTM } \\
\text { (Universal Transverse Mercator) coordinates }\end{array}$ & $\mathrm{X}$ (Easting) & $438.711 \mathrm{~km}$ \\
\cline { 3 - 4 } & & Y (Northing) \\
\hline Grid Spacing $(\Delta \mathrm{X})$ & & $3673.880 \mathrm{~km}$ \\
Domain size & Number of X grid cells & 16 \\
& Number of Y grid cells & 16 \\
Origin of Projection & Latitude & $33^{\circ} \mathrm{N}$ \\
& Longitude & $44^{\circ} \mathrm{E}$ \\
Projection & Universal Transverse Mercator (UTM) & $38^{\circ} \mathrm{N}$ \\
UTM Zone & & 8 \\
Number of vertical layers & UTC + 03:00 \\
Time Zone & Iraq \\
Region & ASIA/EUR-S \\
Datum code & & \\
\hline
\end{tabular}

\subsection{Characteristics of the Point Sources}

The emission rates of the four pollutants were estimated from monthly fuel usage at each of the twelve units (12-point sources) for each six-month period (June, July, and August, 2013; December, 2013; January; and February, 2014). The emission rate assumed constant for the one-month modeling period. Table 1 shows the modeled Daura refinery point sources used in the CALPUFF model simulation.

\subsection{Emission Rate Estimates}

Emission rates of the four pollutants $\left(\mathrm{SO}_{2}, \mathrm{CO}, \mathrm{NO}_{2}\right.$, and $\mathrm{PM}_{2.5}$ ), and stack gas exit velocity were calculated for all twelve production unit stacks for the six months modeled using the actual amounts of fuel that was consumed in Daura refinery during each month. The equations for calculating emission rates and stack gas exit velocity taken from Gzar, (1998) and performed within a FORTRAN computer program. The stack gas exit velocity calculated by:

$v=F_{V} /\left[\pi(d / 2)^{2}\right]$

where

$v \quad=$ stack exit velocity $\left(\mathrm{m} \mathrm{s}^{-1}\right)$
$F_{V}=$ volumetric stack flow rate $\left(\mathrm{m}^{3} \mathrm{~s}^{-1}\right)$

$d=$ stack diameter $(\mathrm{m})$

The volumetric flow rate calculated using:

$F_{V}=\left(F_{m} / \boldsymbol{\rho}_{\mathrm{g}}\right)$

where

$F_{m} \quad=$ mass flow rate of gas $\left(\mathrm{kg} \mathrm{hr}^{-1}\right)$

$\boldsymbol{\rho}_{\mathrm{g}} \quad=$ density of gas $\left(\mathrm{kg} \mathrm{m}^{-3}\right)$

The emission rate for $\mathrm{SO}_{2}$ calculated as:

$Q=\left(M W_{\mathrm{SO}_{2}} M_{S}\right) /\left(M W_{S}\right)$

where

$M W_{\mathrm{SO}_{2}}=$ molecular weight of $\mathrm{SO}_{2}\left(64 \mathrm{~g} \mathrm{~mol}^{-1}\right)$

$M_{S} \quad=$ mass of sulfur in fuel burned per hour of operation $\left(\mathrm{kg} \mathrm{hr}^{-1}\right)$

$M W_{S} \quad=$ molecular weight of sulfur $\left(32 \mathrm{~g} \mathrm{~mol}^{-1}\right)$ 
The emission rate for $\mathrm{CO}$ calculated as:

$Q=M f_{C O} F_{m}$

where

$M f_{C O}=$ mass fraction of $\mathrm{CO}$ in exit gas $(0.0045 \mathrm{~kg})$

$F_{m} \quad=$ mass release rate of gas from stack $\left(\mathrm{kg} \mathrm{hr}^{-1}\right)$

The emission rate for $\mathrm{NO}_{2}$ calculated as:

$Q=E F_{\mathrm{NO}_{2}} V$

where

$E F_{\mathrm{NO}_{2}}=$ emission factor for $\mathrm{NO} 2\left(8.272 \mathrm{~kg} \mathrm{NO}_{2} \mathrm{~m}^{-3}\right.$ of fuel $)$

$V \quad=$ volume of fuel burned per hour $\left(\mathrm{m}^{3} \mathrm{hr}^{-1}\right)$

The emission rate for $\mathrm{PM}_{2.5}$ calculated with Equation 5 substituting the emission factor for $\mathrm{PM}_{2.5}$ of $2.396 \mathrm{~kg} \mathrm{PM}_{2.5} \mathrm{~m}^{-3}$ of fuel for $E F_{\mathrm{NO}_{2}}$.

\subsection{Grid Settings of the Study Domain}

The first step in a CALPUFF model simulation is defining the extent of the model domain, the horizontal and vertical grid spacing, and appropriate map projection including the reference point, which is the southwest corner of the model domain. The time zone that the model domain resides in also needed. The grid system consisting of NZ vertical layers and $\mathrm{NX} \times \mathrm{NY}$ square horizontal grid cells of size $X$. The grid spacing of the vertical layers can be variable. Table 2 shows the grid setting in the model simulation for the study domain in Baghdad.

Most of the stack height of the Daura refinery around 30 $\mathrm{m}$, the height of the mixing layer expected was $120 \mathrm{~m}$. In addition, the vertical layers, which considered (in CALPUFF model pro-cessing) it is for eight layers until $380 \mathrm{~m}$.

\section{Methodology}

This section presents the general methodology used in the CALPUFF atmospheric dispersion modeling including data flow, the conceptual framework, and mathematical basis of the model.

\subsection{Modeling System Used in the Present Work}

The CALPUFF modeling system is an advanced nonsteady-state Lagrangian Gaussian puff dispersion model for the simulation of pollution dispersion and deposition in time and space for varying meteorological conditions. A Gaussian distribution describes the spatial distribution of the mass in each puff. The concentration at each puff position ( $\mathrm{x}, \mathrm{y}, \mathrm{z}$ in Cartesian coordinates) calculated according to Equation (6) (User guide EPA 1995; Scire et al., 2000; and Lee et al., 2014):

$$
\begin{aligned}
C(x, y, z)= & \frac{Q}{(2 \pi)^{\frac{3}{2}} \boldsymbol{\sigma}_{x} \boldsymbol{\sigma}_{y} \boldsymbol{\sigma}_{z}} \exp \left\{-\frac{1}{2}\left(\frac{x}{\boldsymbol{\sigma}_{x}}\right)^{2}\right\} \exp \left\{-\frac{1}{2}\left(\frac{y}{\boldsymbol{\sigma}_{y}}\right)^{2}\right\} \\
& \left\{\exp \left[-\frac{1}{2}\left(\frac{z+h}{\boldsymbol{\sigma}_{z}}\right)^{2}\right] \exp \left[-\frac{1}{2}\left(\frac{z-h}{\boldsymbol{\sigma}_{z}}\right)^{2}\right]\right\}
\end{aligned}
$$

where

$C=$ the concentration at location $\mathrm{x}, \mathrm{y}, \mathrm{z}\left(\mathrm{g} \mathrm{m}^{-3}\right)$

$Q=$ the pollutant mass in the puff $(\mathrm{g})$

$\boldsymbol{\sigma}_{x}=$ standard deviation of the Gaussian distributions in direction of wind $(\mathrm{m})$

$\boldsymbol{\sigma}_{y}=$ standard deviation of the Gaussian distributions in the crosswind direction $(\mathrm{m})$

$\boldsymbol{\sigma}_{z}=$ standard deviation of the Gaussian distributions in the vertical direction $(\mathrm{m})$

$h=$ height of the puff center above the ground (m)

The CALPUFF modeling system is comprised of three modules, CALMET, CALPUFF, and CALPOST. The CALMET module computes three-dimensional wind fields and temperature profiles from surface and upper air meteorological data, adjusting for terrain influences. The CALPUFF module is the Lagrangian puff model that uses the wind fields calculated in CALMET to transfer and disperse puffs in the model domain. The CALPOST module is a post processor for CALPUFF results.

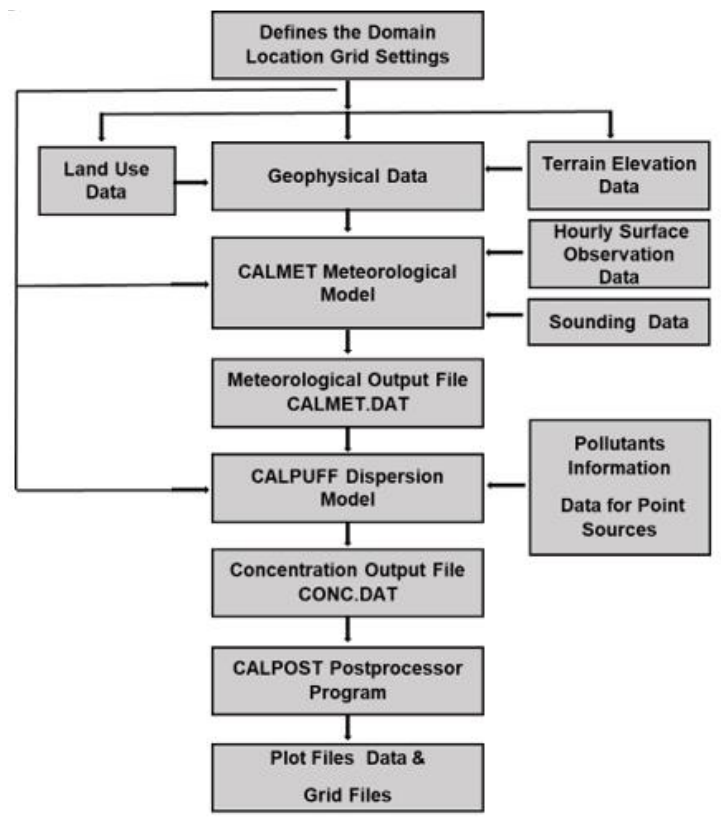

Figure 2. Flow chart of CALPUFF model which applied in the present work to perform the simulation of pollutants at the study area. 
To predict the concentration of the pollutants $\left(\mathrm{SO}_{2}, \mathrm{CO}\right.$ $\mathrm{NO}_{2}$, and $\mathrm{PM}_{2.5}$ ) in the model domain, the CALMET model used to produce the gridded meteorological data file (CALMET.DAT). The pollutant emission rates calculated in an earlier step input into the CALPUFF model to produce gridded concentration files (CONC.DAT). The CALPOST module then used to process the CONC.DAT file to produce time-averaged concentrations across the modeling grid. The overall process illustrated in Figure 2.

\subsection{CALMET Data Requirements}

CALMET designed to use surface and upper air meteorological observations that taken routinely at airports and other recording stations. Hourly surface data of wind speed, wind direction, ceiling height, cloud cover, temperature, relative humidity, surface pressure, and precipitation were needed. Twice daily sounding data at 0000 and 1200 GMT required as a minimum for vertical profiles of pressure, elevation, temperature, wind direction, and wind speed. Geophysical data that summarized in the GEO.DAT file used in CALMET to provide terrain eleva-tions and land use categories. Terrain elevations and land use categories obtained from Exponent Engineering and Scientific Consulting website (www.src.com) or from Lakes Environmental website (www.weblakes.com).

\subsection{CALPUFF Data Requirements}

Emission sources and species characteristics along with the CALMET output file (CALMET.DAT) are required input for CALPUFF. Although point, area, and volume sources modeled, in this study only stack point sources used. Stack data include the height, diameter, exit gas velocity, and exit gas temperature. An emission rate for each source and specie required by CALPUFF.

\section{Results and Discussion}

This section presents the results of the modeling study and discusses the results in terms of temporal and spatial variability in monthly average concentration estimates.

\subsection{Analysis of the Pollutant Dispersion}

Model-predicted concentrations in the summer season showed plumes extending toward the southeast because the dominant winds were from the northwest. The plots presented in Figures 3, 4, and 5 represent monthly-average concentrations for June, July, and August respectively (i.e., the summer season). Summers characterized as dry and hot with average temperatures ranging from a low of $21.9^{\circ} \mathrm{C}$ to a high of $46.1{ }^{\circ} \mathrm{C}$.

Figure 3 shows the pollutant dispersion for June 2013. The four pollutants mainly transported to the southeast because of the strong northwesterly winds. Highest concentrations $3 \mathrm{~km}$ from the refinery was $0.0096,0.0096,0.0006$, and $0.00018 \mathrm{~g} \mathrm{~m}^{-3}$ for $\mathrm{SO}_{2}, \mathrm{CO}, \mathrm{NO}_{2}$, and $\mathrm{PM}_{2.5}$ respectively. High pollutant concentrations observed east and west of the refinery, and extended to the south and east of the refinery. The dispersion patterns of the four species were similar to one another, only dif- fering in magnitude. Highest concentrations observed along the Al-Imam Al-Hassan quarter in the easterly side, the residence of refinery employee in the westerly side, and Daura Express Highway in the southerly side of the refinery.

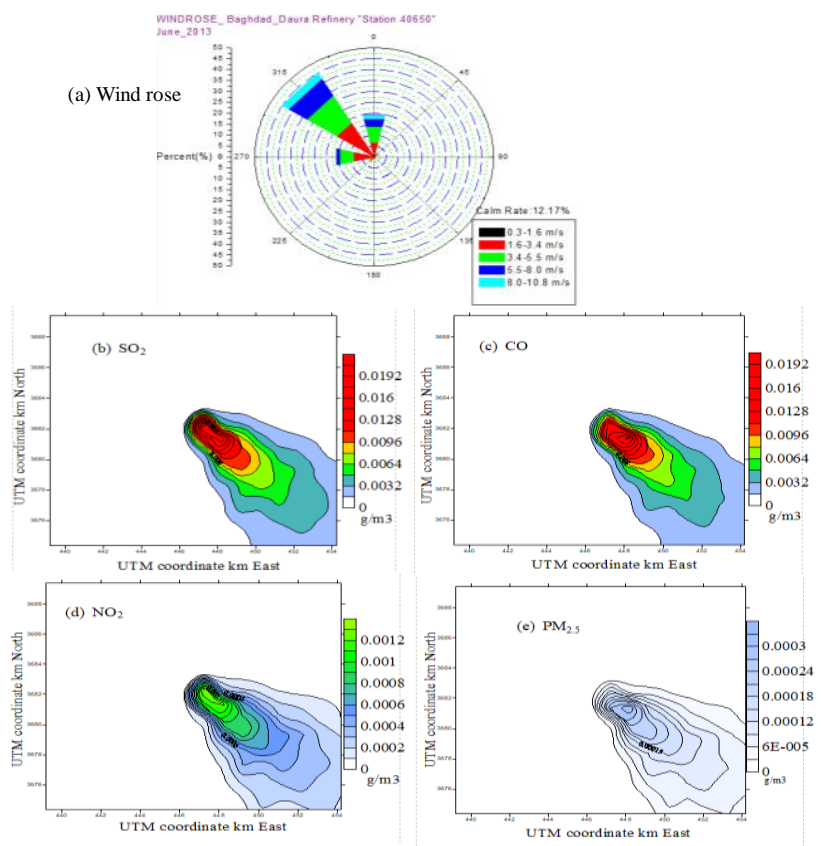

Figure 3. (a) Wind rose, and predicted isopleths for the 10 highest 1-hour average of the pollutant concentration for (b) $\mathrm{SO}_{2}$, (c) $\mathrm{CO}$, (d) $\mathrm{NO}_{2}$, and (e) $\mathrm{PM}_{2.5}$ on June 2013.

Figure 4 shows the pollutant dispersion for July 2013. Winds primarily blew from the northwest, with a little wind from the north and east direction as shown in Figure 4 (a). Thus, the pollutants $\left(\mathrm{SO}_{2}, \mathrm{CO}, \mathrm{NO}_{2}\right.$, and $\left.\mathrm{PM}_{2.5}\right)$ dispersed to the southeast. The highest pollutant concentrations occurred to the west and southeast corner of the Daura refinery, and extended in a southeast direction. Highest concentrations $3 \mathrm{~km}$ from the refinery was $0.008,0.0072,0.00064$, and $0.00016 \mathrm{~g} \mathrm{~m}^{-3}$ for $\mathrm{SO}_{2}, \mathrm{CO}, \mathrm{NO}_{2}$, and $\mathrm{PM}_{2.5}$ respectively. The south part of AlImam Al-Hassan quarter in the easterly side, the residence of refinery employee in the westerly side, and Daura Express Highway and Al-Zafraniya city southeast of the refinery had the highest pollutant concentrations.

Figure 5 shows the results of the four species for August 2013. The wind direction is very similar to the previous summer's months (June and July). Wind from the northwest are dominate, with low frequency winds from north and east direction. Highest concentrations $4 \mathrm{~km}$ from the refinery was 0.0096, 0.0096, 0.0008, and $0.00018 \mathrm{~g} \mathrm{~m}^{-3}$ for $\mathrm{SO}_{2}, \mathrm{CO}, \mathrm{NO}_{2}$, and $\mathrm{PM}_{2.5}$ respectively. Thus, higher concentrations extended farther southeast than for the previous two months. The highest concentrations in urban areas shown at Al-Zafraniya city and Daura Express Highway southeast of the refinery, refinery employee residence west of the refinery, and Al-Imam Al-Hassan quarter in the easterly side. 


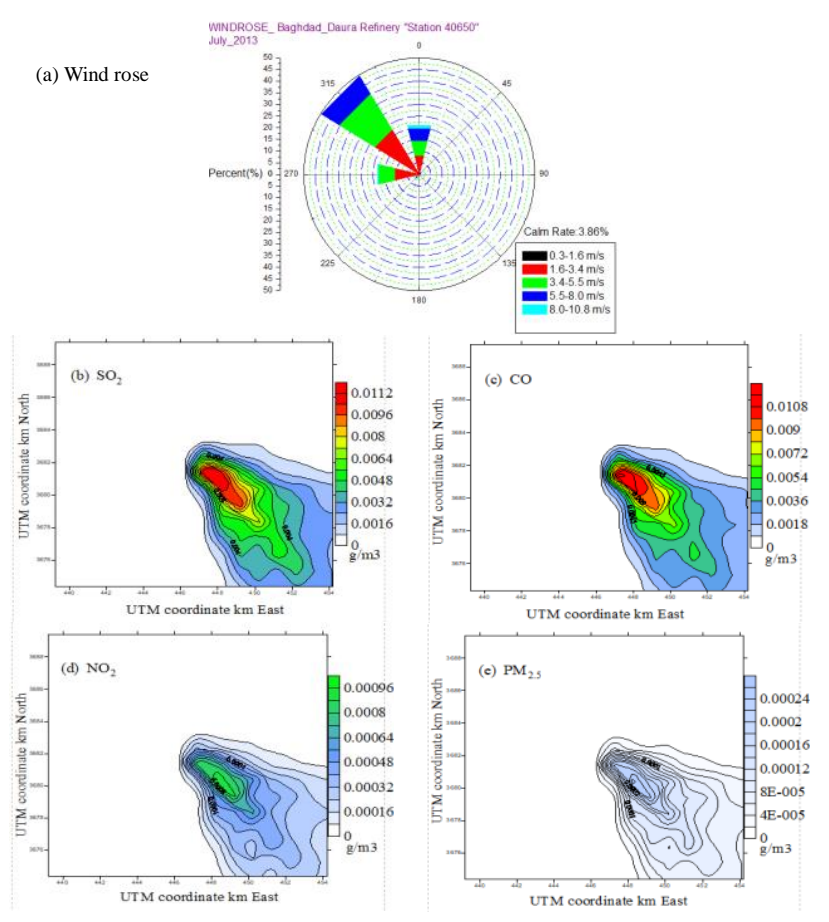

Figure 4. (a) Wind rose, and predicted isopleths for the 10 highest 1-hour average of the pollutant concentration for (b) $\mathrm{SO}_{2}$, (c) $\mathrm{CO}$, (d) $\mathrm{NO}_{2}$, and (e) $\mathrm{PM}_{2.5}$ on July 2013.

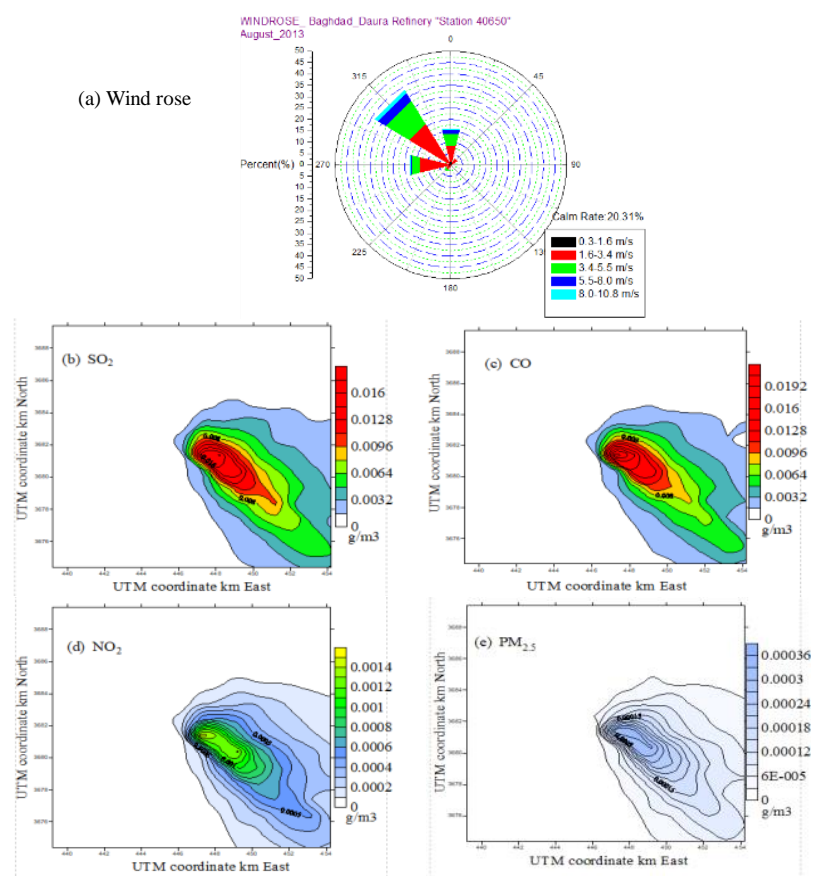

Figure 5. Wind rose (a), and predicted isopleths for the 10 highest 1-hour average of the pollutant concentration for (b) $\mathrm{SO}_{2}$, (c) $\mathrm{CO}$, (d) $\mathrm{NO}_{2}$, and (e) $\mathrm{PM}_{2.5}$ on Aug. 2013.

The important notes for this summer's month that the pol- lutants dispersed directly towards the southeast direction from the Daura refinery site, therefore the urban areas at this location very affected by the high concentration of air pollution, leads too many respiratory problems to the people lived there.

Figures 6 to 8 show the dispersion patters for December 2013, January 2014, and February 2014 and represent the winter season in Baghdad. Winter characterized by wet, cool weather with average temperatures ranging from a low of 0.8 ${ }^{\circ} \mathrm{C}$ to a high of $23.2^{\circ} \mathrm{C}$.

Figure 6 shows the dispersion results of the four pollutants for December 2013. The dominant winds were from the northwest, north, and west, with lower frequencies from the south and southeast. Two regions of high concentration extending $6 \mathrm{~km}$ from the refinery observed southeast and north of the refinery site. The highest concentrations in these two areas were $0.0084,0.0078,0.00064$, and $0.00016 \mathrm{~g} \mathrm{~m}^{-3}$, for $\mathrm{SO}_{2}, \mathrm{CO}$, $\mathrm{NO}_{2}$, and $\mathrm{PM}_{2.5}$ respectively. The lowest pollutant concentrations observed southwest of the refinery.

Each area of Daura Express Highway and Al-Zafraniya city in the south-easterly and southerly direction, Al-Karada city in the northerly direction, and Al-Imam Al-Hassan quarter and Camp Sarah quarter in the easterly side had the highest concentration of pollutants in this month.

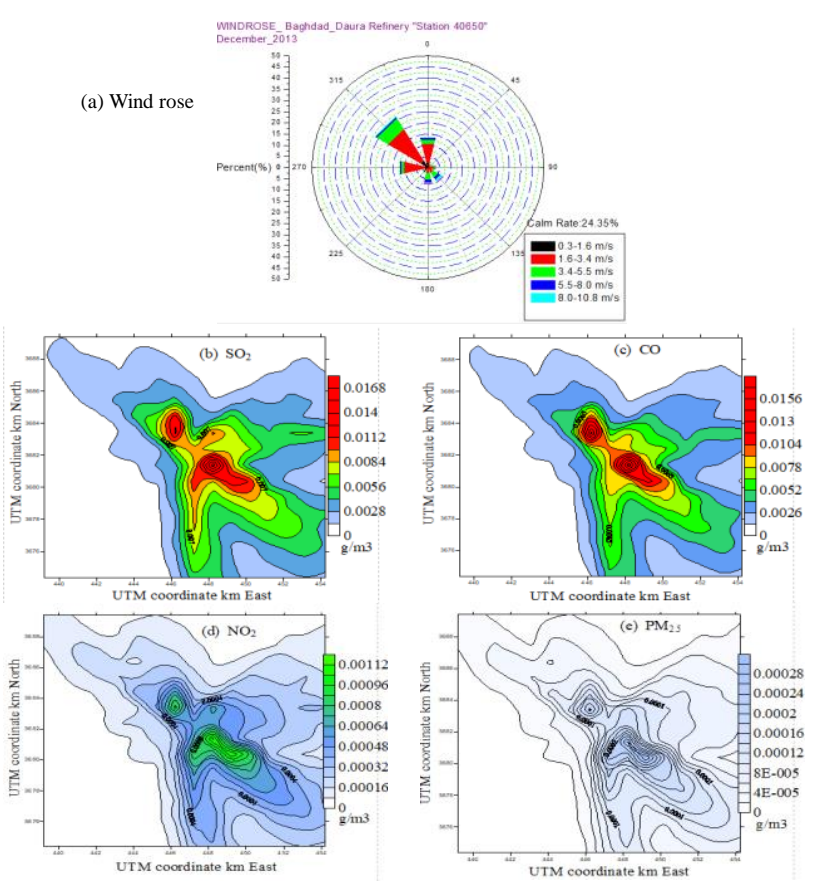

Figure 6. (a) Wind rose, and predicted isopleths for the 10 highest 1-hour average of the pollutant concentration for (b) $\mathrm{SO}_{2}$, (c) $\mathrm{CO}$, (d) $\mathrm{NO}_{2}$, and (e) $\mathrm{PM}_{2.5}$ on Dec. 2013.

Figure 7 shows the dispersion results of the four pollutants for January 2014. The dominant winds were from the northwest, north, and southeast, with lower frequencies from the south and southeast. Two regions of high concentration extending $6 \mathrm{~km}$ from the refinery observed southeast and north of 
the refinery site. The highest concentration of the $\mathrm{SO}_{2}$ and $\mathrm{CO}$ covered refinery site and extended more than $7 \mathrm{~km}$ south, north, east, and west of the refinery. The highest concentrations of $\mathrm{NO}_{2}$ and $\mathrm{PM}_{2.5}$ viewed south of the refinery. The highest pollutant concentrations were $0.0084,0.0084,0.00072$, and $0.00018 \mathrm{~g} \mathrm{~m}^{-3}$ for $\mathrm{SO}_{2}, \mathrm{CO}, \mathrm{NO}_{2}$, and $\mathrm{PM}_{2.5}$ respectively. The pattern of pollutant dispersion was star shaped resulting from winds blowing from multiple directions at measurable frequencies. The highest pollutant concentrations in urban areas observed along the Daura Express Highway and Al-Zafraniya city south and southeast from the refinery, Al-Karada city and International area in Karadat Maryam in the north side, Al-Imam Al-Hassan quarter in the easterly side, and the residence of refinery employees in the westerly side.

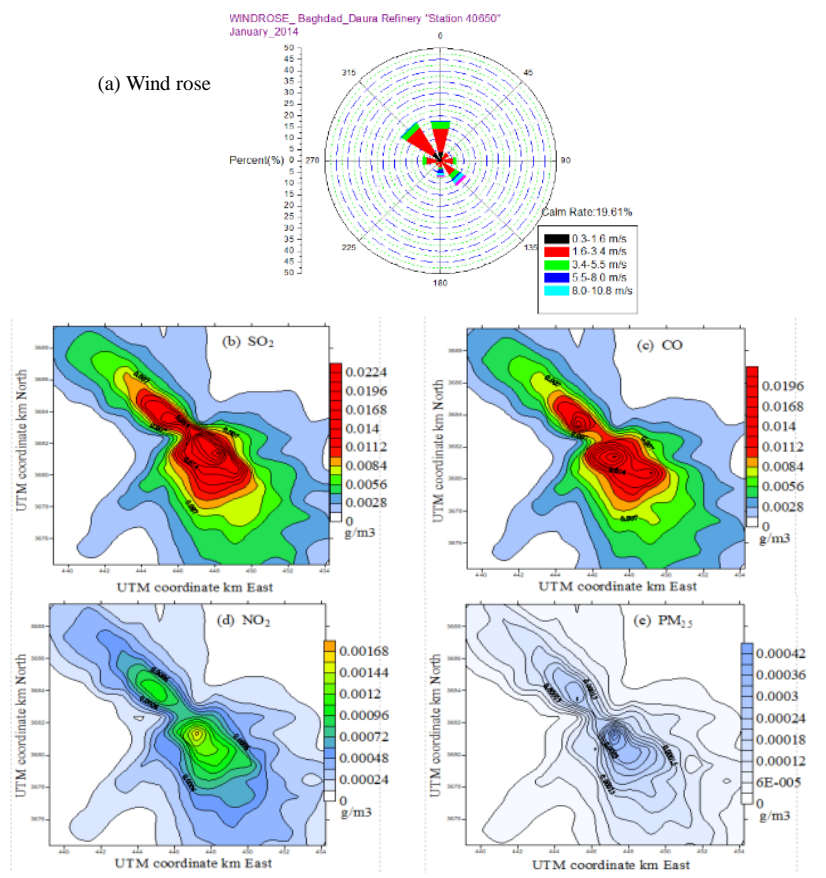

Figure 7. (a) Wind rose, and predicted isopleths for the 10 highest 1-hour average of the pollutant concentration for (b) $\mathrm{SO}_{2}$, (c) $\mathrm{CO}$, (d) $\mathrm{NO}_{2}$, and (e) $\mathrm{PM}_{2.5}$ on Jan. 2014.

Figure 8 shows the dispersion results of the four pollutants for February 2014. High pollutant concentrations were observed southeast and northwest of the refinery site. The general pattern of the pollutant dispersion reflects strong winds from northwest and southeast. Highest pollutant concentrations viewed along the Daura Express Highway south of the refinery and AlKarada city north of the refinery.

In winter's month, the spices moved along the southeast, northwest, and west direction of the Daura refinery site, therefore more urban areas around the refinery suffered from these poison gasses than summer and leads to the high concentration of air pollution. The behavior of pollutants dispersion in winter proved that this season in Baghdad are worse than summer, even the temperature reached around $40 \sim 50{ }^{\circ} \mathrm{C}$ in June, July, and August, and many peoples thinks summer season more polluted than winter.

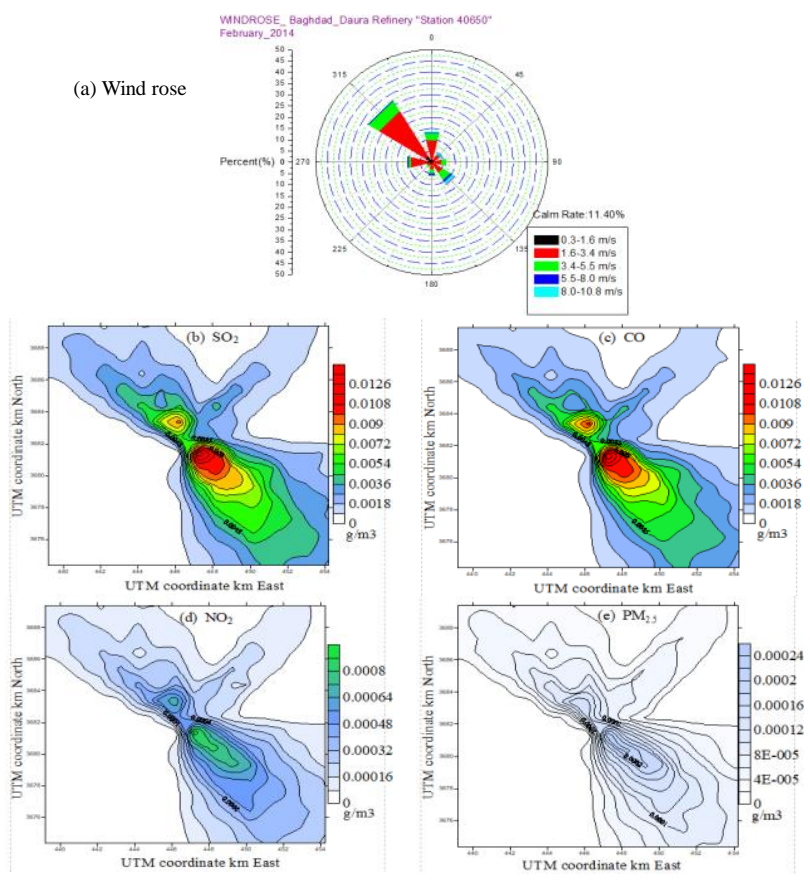

Figure 8. Wind rose (a), and predicted isopleths for the 10 highest 1-hour average of the pollutant concentration for (b) $\mathrm{SO}_{2}$, (c) $\mathrm{CO}$, (d) $\mathrm{NO}_{2}$, and (e) $\mathrm{PM}_{2.5}$ on Feb. 2014.

\subsection{Seasonal Variability of Predicted Pollutant Concentra- tions}

Monthly average pollutant concentrations calculated at fixed locations of the urban areas. Table 3 shows the seasonal variability of the predicted pollutants.

Monthly-average pollutant concentrations for the summer months illustrated in Figure 9. Highest concentrations for $\mathrm{SO}_{2}$ and $\mathrm{CO}$ observed along the Daura Express Highway, the refinery employee residences, Al-Imam Al-Hassan quarter, and AlZafraniya city because of winds predominately from northeast.

The other urban areas, Al-Karada city, Al-Jamaia quarter, Camp Sarah quarter, and International area at Karadat Maryam did not exhibit positive concentrations because winds did not blow in the direction of these receptors. The highest pollutant concentrations during the summer months observed in August at Daura Express Highway as shown in Figure 9.

Figure 10 illustrates monthly average concentrations of the four species in urban areas for the winter season. Highest pollutant concentrations observed at the Daura Express Highway and refinery employee residences for the month of January. Winds were generally more variable in direction during the winter months resulting in greater spatial spreading of pollutant plumes in the model domain, and thus all locations exhibited concentrations greater than $1 \times 10^{-5} \mathrm{~g} \mathrm{~m}^{-3}$. 
Table 3. Seasonal Variability of Predicted Monthly Average Concentrations of $\mathrm{SO}_{2}, \mathrm{CO}, \mathrm{NO}_{2}$, and PM2.5 in Urban Areas for June, July, August, and December 2013, and January and February of 2014

\begin{tabular}{|c|c|c|c|c|c|c|c|}
\hline Urban area & Pollutants & $\begin{array}{l}\text { June } 2013 \\
\text { pollutant conc. } \\
\mathrm{g} / \mathrm{m}^{3}\end{array}$ & $\begin{array}{l}\text { July } 2013 \\
\text { pollutant conc. } \\
\mathrm{g} / \mathrm{m}^{3}\end{array}$ & $\begin{array}{l}\text { Aug. } 2013 \\
\text { pollutant conc. } \\
\mathrm{g} / \mathrm{m}^{3}\end{array}$ & $\begin{array}{l}\text { Dec. } 2013 \\
\text { pollutant conc. } \\
\mathrm{g} / \mathrm{m}^{3}\end{array}$ & $\begin{array}{l}\text { Jan. } 2014 \\
\text { pollutant conc. } \\
\mathrm{g} / \mathrm{m}^{3}\end{array}$ & $\begin{array}{l}\text { Feb. } 2014 \\
\text { pollutant conc. } \\
\mathrm{g} / \mathrm{m}^{3}\end{array}$ \\
\hline \multirow{4}{*}{$\begin{array}{l}\text { Daura express } \\
\text { highway (D) }\end{array}$} & $\mathrm{SO}_{2}$ & 0.01500 & 0.01120 & 0.01700 & 0.01500 & 0.02000 & 0.01100 \\
\hline & $\mathrm{CO}$ & 0.01700 & 0.01080 & 0.01900 & 0.01560 & 0.01900 & 0.01100 \\
\hline & $\mathrm{NO}_{2}$ & 0.00100 & 0.00070 & 0.00130 & 0.00085 & 0.00130 & 0.00080 \\
\hline & $\mathrm{PM}_{2.5}$ & 0.00030 & 0.00022 & 0.00034 & 0.00022 & 0.00030 & 0.00020 \\
\hline \multirow{4}{*}{$\begin{array}{l}\text { Residence of } \\
\text { refinery } \\
\text { employers (R) }\end{array}$} & $\mathrm{SO}_{2}$ & 0.00640 & 0.00480 & 0.00960 & 0.00650 & 0.01680 & 0.00720 \\
\hline & $\mathrm{CO}$ & 0.00960 & 0.00810 & 0.01160 & 0.00650 & 0.01960 & 0.00600 \\
\hline & $\mathrm{NO}_{2}$ & 0.00070 & 0.00048 & 0.00040 & 0.00056 & 0.00132 & 0.00056 \\
\hline & $\mathrm{PM}_{2.5}$ & 0.00021 & 0.00012 & 0.00012 & 0.00012 & 0.00036 & 0.00018 \\
\hline \multirow{4}{*}{$\begin{array}{l}\text { Al-Imam Al- } \\
\text { Hassan quarter } \\
\text { (H) }\end{array}$} & $\mathrm{SO}_{2}$ & 0.00800 & 0.00280 & 0.00800 & 0.00840 & 0.01000 & 0.00360 \\
\hline & $\mathrm{CO}$ & 0.00480 & 0.00320 & 0.00800 & 0.00880 & 0.01080 & 0.00270 \\
\hline & $\mathrm{NO}_{2}$ & 0.00040 & 0.00016 & 0.00040 & 0.00064 & 0.00065 & 0.00032 \\
\hline & $\mathrm{PM}_{2.5}$ & 0.00009 & 0.00004 & 0.00010 & 0.00016 & 0.00018 & 0.00012 \\
\hline \multirow{4}{*}{$\begin{array}{l}\text { Al-Zafraniya } \\
\text { city }(Z)\end{array}$} & $\mathrm{SO}_{2}$ & 0.00240 & 0.00240 & 0.00340 & 0.00280 & 0.00280 & 0.00270 \\
\hline & $\mathrm{CO}$ & 0.00240 & 0.00220 & 0.00320 & 0.00260 & 0.00210 & 0.00180 \\
\hline & $\mathrm{NO}_{2}$ & 0.00030 & 0.00024 & 0.00030 & 0.00024 & 0.00018 & 0.00016 \\
\hline & $\mathrm{PM}_{2.5}$ & 0.00009 & 0.00009 & 0.00009 & 0.00009 & 0.00009 & 0.00009 \\
\hline \multirow{4}{*}{$\begin{array}{l}\text { Al-Karada city } \\
(\mathrm{K})\end{array}$} & $\mathrm{SO}_{2}$ & 0.00000 & 0.00000 & 0.00000 & 0.01120 & 0.00700 & 0.00450 \\
\hline & $\mathrm{CO}$ & 0.00000 & 0.00000 & 0.00000 & 0.00780 & 0.00700 & 0.00360 \\
\hline & $\mathrm{NO}_{2}$ & 0.00000 & 0.00000 & 0.00000 & 0.00064 & 0.00048 & 0.00040 \\
\hline & $\mathrm{PM}_{2.5}$ & 0.00000 & 0.00000 & 0.00000 & 0.00020 & 0.00012 & 0.00012 \\
\hline \multirow{4}{*}{$\begin{array}{l}\text { Al-Jamaia } \\
\text { quarter (J) }\end{array}$} & $\mathrm{SO}_{2}$ & 0.00000 & 0.00000 & 0.00000 & 0.00700 & 0.00980 & 0.00360 \\
\hline & $\mathrm{CO}$ & 0.00000 & 0.00000 & 0.00000 & 0.00650 & 0.00980 & 0.00360 \\
\hline & $\mathrm{NO}_{2}$ & 0.00000 & 0.00000 & 0.00000 & 0.00056 & 0.00132 & 0.00032 \\
\hline & $\mathrm{PM}_{2.5}$ & 0.00000 & 0.00000 & 0.00000 & 0.00010 & 0.00021 & 0.00010 \\
\hline \multirow{4}{*}{$\begin{array}{l}\text { Camp Sarah } \\
\text { quarter (S) }\end{array}$} & $\mathrm{SO}_{2}$ & 0.00000 & 0.00000 & 0.00000 & 0.00420 & 0.00140 & 0.00270 \\
\hline & $\mathrm{CO}$ & 0.00000 & 0.00000 & 0.00000 & 0.00260 & 0.00070 & 0.00270 \\
\hline & $\mathrm{NO}_{2}$ & 0.00000 & 0.00000 & 0.00000 & 0.00024 & 0.00010 & 0.00024 \\
\hline & $\mathrm{PM}_{2.5}$ & 0.00000 & 0.00000 & 0.00000 & 0.00008 & 0.00000 & 0.00008 \\
\hline \multirow{4}{*}{$\begin{array}{l}\text { International } \\
\text { area- Karadat } \\
\text { Maryam (M) }\end{array}$} & $\mathrm{SO}_{2}$ & 0.00000 & 0.00000 & 0.00000 & 0.00560 & 0.01120 & 0.00360 \\
\hline & $\mathrm{CO}$ & 0.00000 & 0.00000 & 0.00000 & 0.00390 & 0.01050 & 0.00360 \\
\hline & $\mathrm{NO}_{2}$ & 0.00000 & 0.00000 & 0.00000 & 0.00040 & 0.00108 & 0.00040 \\
\hline & $\mathrm{PM}_{2.5}$ & 0.00000 & 0.00000 & 0.00000 & 0.00008 & 0.00021 & 0.00008 \\
\hline
\end{tabular}

Table 4. Domain Modeling Settings for Comparison on August 1997

\begin{tabular}{|c|c|c|c|}
\hline \multirow{2}{*}{\multicolumn{2}{|c|}{$\begin{array}{l}\text { Grid origin (reference point defining domain location) in UTM (Universal Transverse } \\
\text { Mercator) coordinates }\end{array}$}} & \multirow{2}{*}{$\frac{\mathrm{X} \text { (Easting) }}{\mathrm{Y} \text { (Northing) }}$} & \multirow{2}{*}{$\begin{array}{l}445.61 \mathrm{~km} \\
3679.185 \mathrm{~km}\end{array}$} \\
\hline & & & \\
\hline Grid Spacing $(\Delta X)$ & & & $0.5 \mathrm{~km}$ \\
\hline \multirow[t]{2}{*}{ Domain size } & Number of $\mathrm{X}$ grid cells & & 6 \\
\hline & Number of Y grid cells & & 8 \\
\hline \multirow[t]{2}{*}{ Origin of Projection } & Latitude & & $33^{\circ} \mathrm{N}$ \\
\hline & Longitude & & $44^{\circ} \mathrm{E}$ \\
\hline Projection & Universal Transverse Mercator (UTM) & & \\
\hline UTM Zone & & & $38^{\circ} \mathrm{N}$ \\
\hline Number of vertical la & & & 8 \\
\hline Time Zone & & & $\mathrm{UTC}+03: 00$ \\
\hline Region & & & Iraq \\
\hline Datum code & & & ASIA/EUR-S \\
\hline
\end{tabular}




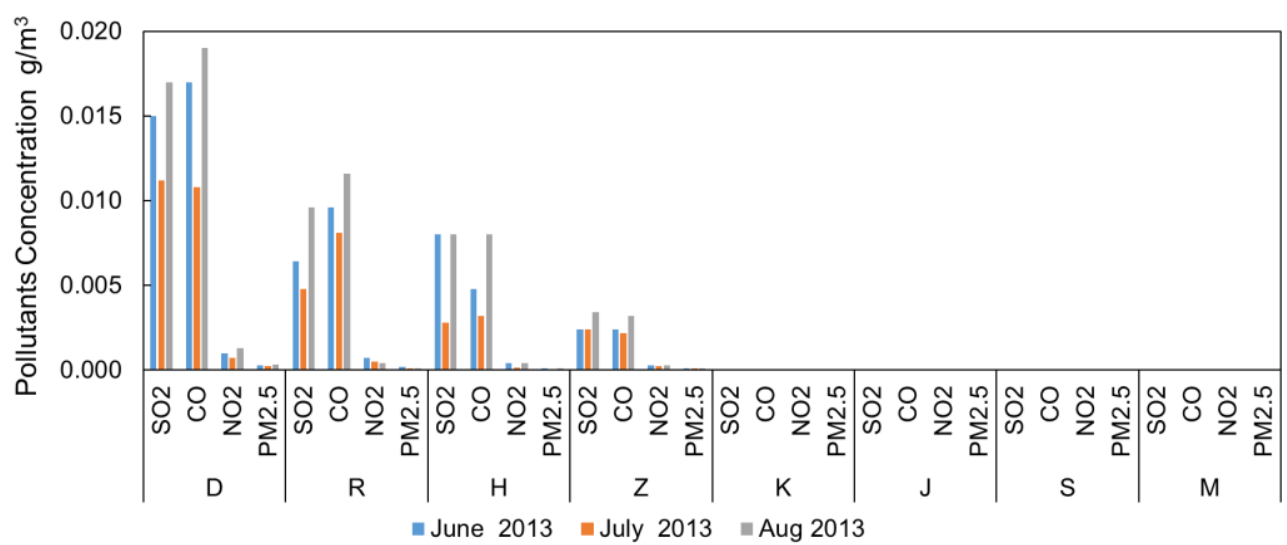

Figure 9. Bar chart of the monthly average pollutant concentration within the urban areas for the summer season.

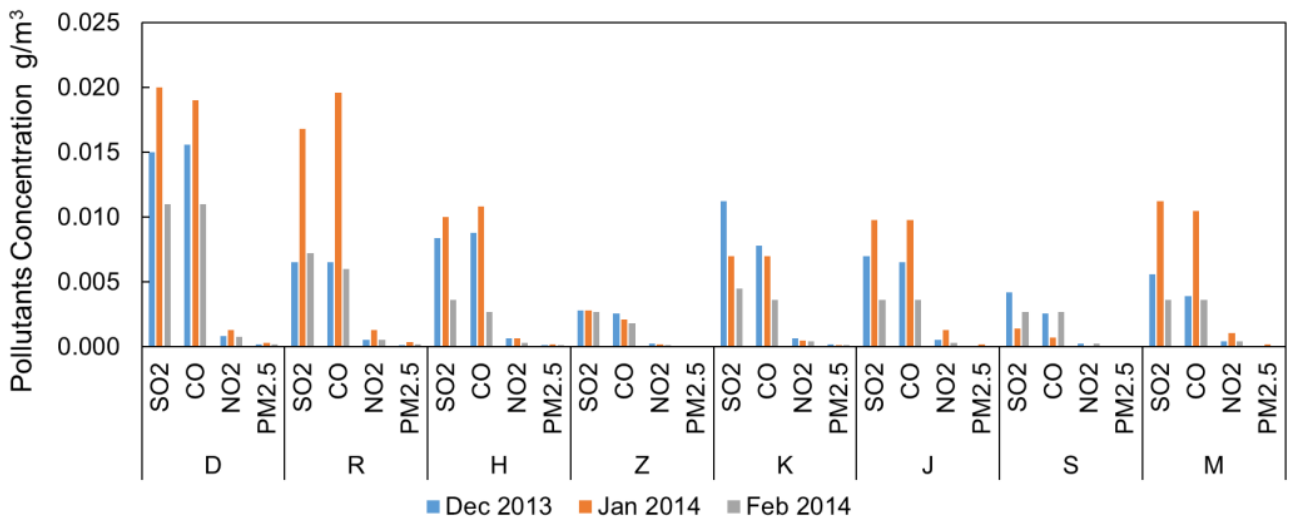

Figure 10. Bar chart of the monthly average pollutant concentration within the urban areas for the winter season.

\subsection{Evaluation of CALPUFF Model}

In order to evaluate the accuracy of CALPUFF model for prediction of the pollutants concentration in ambient air at the study area, a comparison conducted between the predicted results of this model and the observed results, which measured by Gzar, (1998) in August 1997. The hourly concentration results of CALPUFF were compared with measured ones at two Cases. The first Case on 23 August was better correlation than the second Case on 25 August 1997, however, it showed good agreement for $\mathrm{SO}_{2}, \mathrm{CO}$, and $\mathrm{NO}_{2}$, but for $\mathrm{PM}_{2.5}$ was less agreement.

Figure 11 illustrates the site of the measured point for the observation pollutants in 1997 and the simulation point processed by CALPUFF model. The distance between these two points is about 510 meters to the east.

In order to perform the comparison with the measured point which lay on the $475 \mathrm{~m}$ only from the borders of the refinery, a new grid settings in the model were prepared after checking for many times the probability of the best grid setting for the study domain to get the nearest simulated point (receptor) to the measured point, and also this modeled point should be covered all the (9) point sources in the refinery similar to that in measured point which was depended on the August 1997, and also at the same meteorological conditions. Table 4 Shows the new domain settings to perform the comparison process.

Figures 12 to 15 show the comparison between observed and simulated data for the four pollutants at the two Cases (Case 1 at 23 August and Case 2 at 25 August 1997).

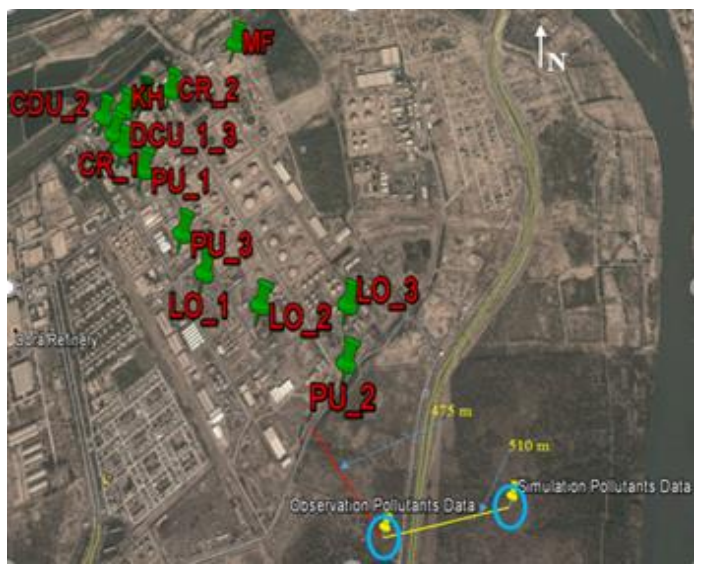

Figure 11. The two blue circles show the site of observation point and simulation point. 

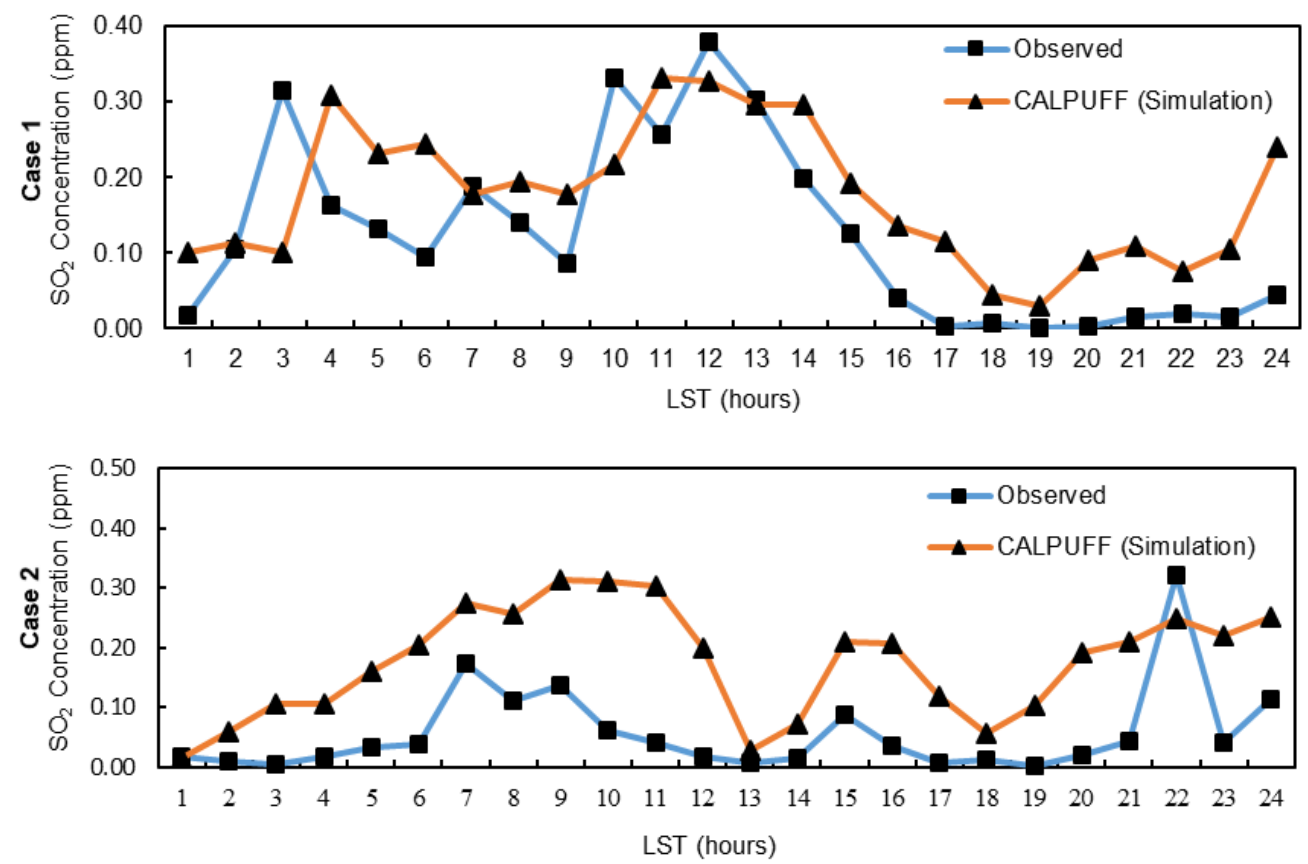

Figure 12. Simulated and observed hourly concentration of $\mathrm{SO}_{2}$ at Case 1 (23 August 1997) and Case 2 (25 August 1997 ).
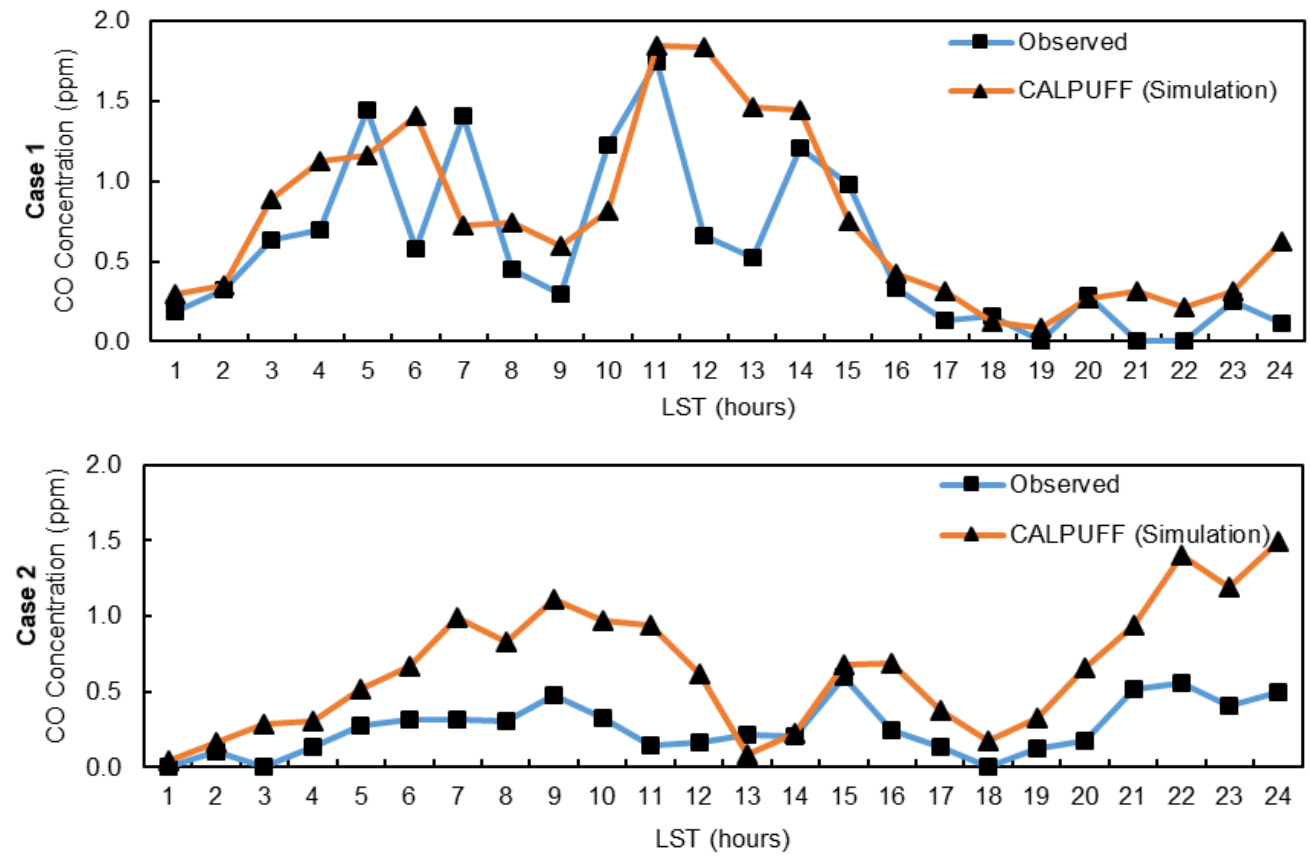

Figure 13. Simulated and observed hourly concentration of CO at Case 1 (23 August 1997) and Case 2 (25 August 1997).

In Figure 12, Case (1) showed good agreement between model and observation results than in Case (2). Figure 13 illustrates that Case (1) shows better agreement than Case (2). In Figure 14, the predicted and observed data in Case (1) had good agreement than Case (2). The two Cases (1) and (2) in Figure 15 had less agreement compared with other cases. CALPUFF model simulation for pollutant gases $\mathrm{SO}_{2}, \mathrm{CO}$, and $\mathrm{NO}_{2}$ had a better correlation than particulate matter $\mathrm{PM}_{2.5}$ at the two Cas- es. In general, the CALPUFF model results overestimated for $\mathrm{SO}_{2}, \mathrm{CO}$, and $\mathrm{NO}_{2}$, but underestimated for $\mathrm{PM}_{2.5}$.

The poor model performance for $\mathrm{PM}_{2.5}$ in Figure 14 may be a result of high natural background concentration of $\mathrm{PM}_{2.5}$ derived from wind-driven suspension of soil. The wind speed was recorded on 23 and 25 August 1997 were around $4 \sim 8.5$ $\mathrm{m} / \mathrm{sec}$ and $3.5 \sim 11 \mathrm{~m} / \mathrm{sec}$, respectively. 

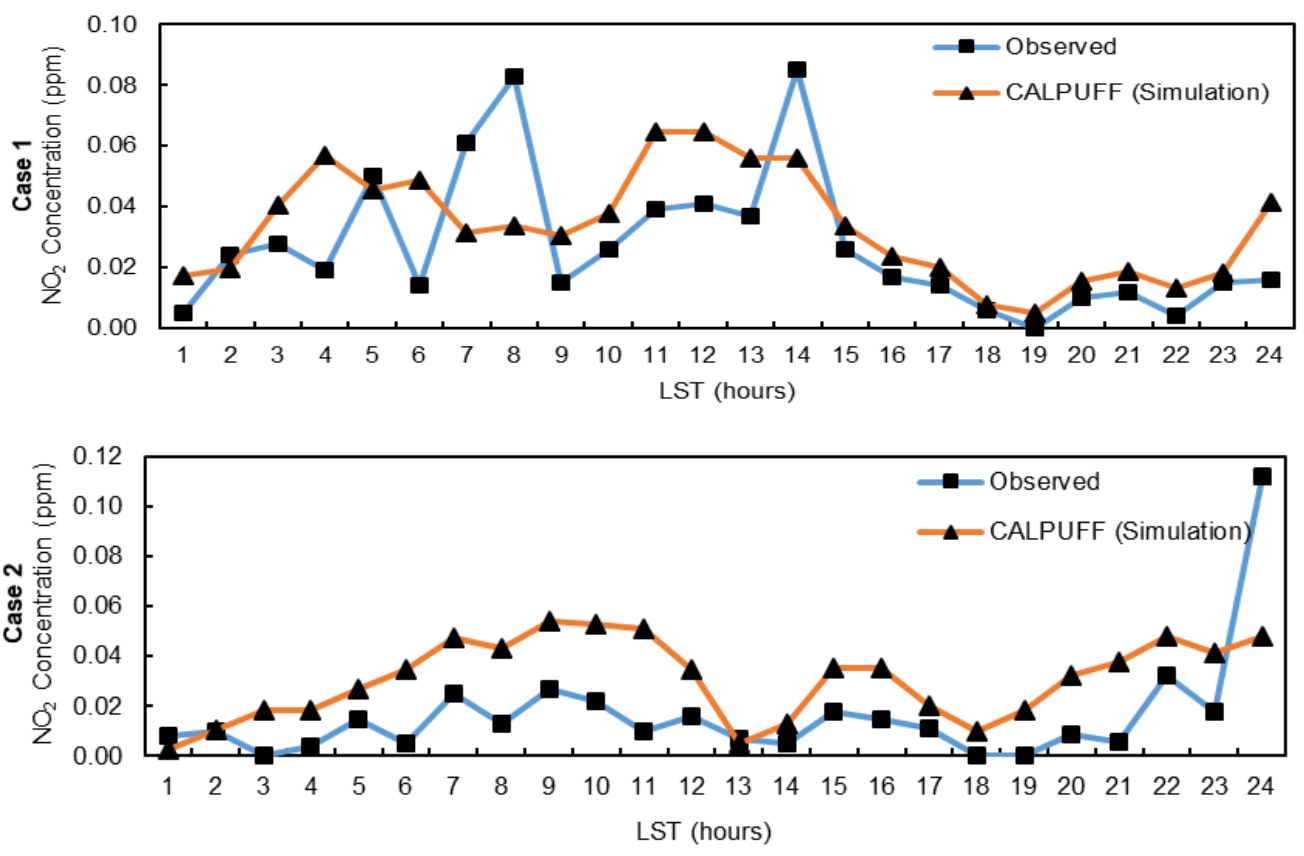

Figure 14. Simulated and observed hourly concentration of $\mathrm{NO}_{2}$ at Case 1 (23 August 1997) and Case 2 (25 August 1997 ).
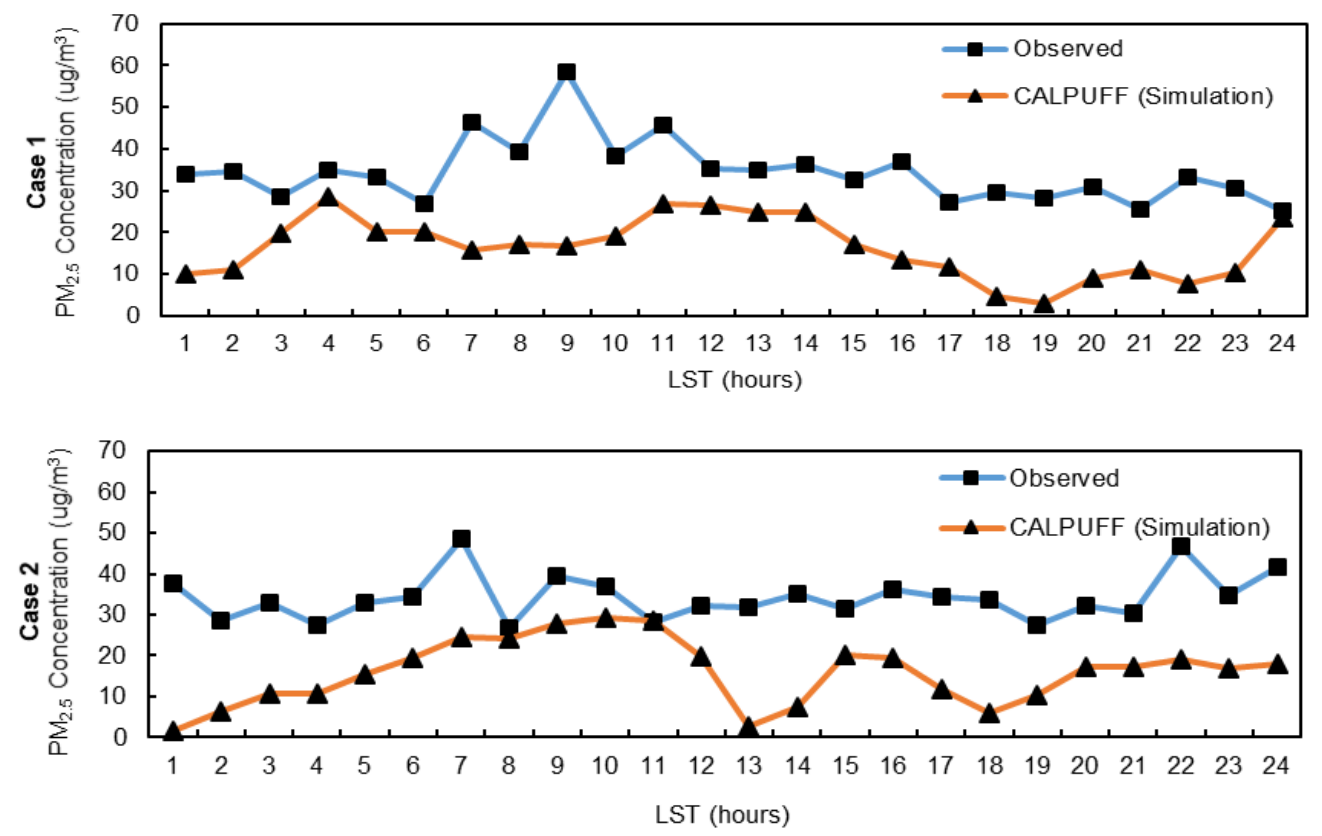

Figure 15. Simulated and observed hourly concentration of $\mathrm{PM}_{2.5}$ at Case 1 (23 August 1997) and Case 2 (25 August 1997).

\section{Conclusions}

In this study we investigated dispersion of four pollutants $\left(\mathrm{SO}_{2}, \mathrm{CO}, \mathrm{NO}_{2}\right.$, and $\left.\mathrm{PM}_{2.5}\right)$ emitted from the Daura refinery in Baghdad during the summer of 2013 and winter of $2013 \sim 2014$ using the CALPUFF modeling system. We calculated the hourly emission rates of pollutants based on the actual amounts of fuel consumed at the refinery. To the best of our knowledge, this is the first application of the CALPUFF modeling system in Baghdad. It provides an opportunity to understand seasonal variability in air quality in the Baghdad region. Three FORTRAN programs written to assist in preparation and processing of these data. One FORTRAN program written to process emission rates and two other programs written to formulate the surface observation, and upper radiosonde data that required in CALMET model running. Meteorological data obtained from 
the General Board for meteorological and seismic monitoring in Baghdad, and geophysical data downloaded from publically accessible internet sites.

Predicated concentrations showed that $\mathrm{SO}_{2}$ and $\mathrm{CO}$ concentrations were higher than that of $\mathrm{NO}_{2}$ and $\mathrm{PM}_{2.5}$. This was due to the higher emission rates of $\mathrm{SO} 2$ and $\mathrm{CO}$ compared to $\mathrm{NO}_{2}$ and $\mathrm{PM}_{2.5}$ during the study period. Dispersion patterns however were similar among the model species.

Spatial distribution of pollutants in the model domain primarily influenced by wind direction. Winds were generally out of the north and northwest and consequently, urban areas south and southeast of the refinery had the highest concentrations. The Daura Express Highway is southeast of the refinery and had the highest concentration of all the urban areas studied. The refinery employee residences, which are west of the refinery, had the second highest concentrations because of its close proximity to the refinery. Isopleth maps offer a clear representation of monthly pollutant dispersion patters in the study domain. Highest pollutant concentrations are in most cases confined to a region close to the refinery, and as expected, decrease with distance from the refinery.

Seasonal variability of predicted pollutant concentrations observed in this study. In general, winter months exhibited higher concentrations than summer months. This was primarily due to a greater preponderance of stable atmospheric conditions and lower wind speeds during winter months resulting in lower pollutant dilution and dispersion. Summer months generally exhibited higher wind speeds and greater atmospheric instability compared to winter months, and thus pollutant concentrations were generally lower. The lack of terrain features resulted in unobstructed transport paths and straight-line plume trajectories.

The high pollutant concentrations observed along the Daura Express Highway and the refinery employee residences suggest measures taken to reduce emissions and pollutant concentration in these areas. Advanced pollution control measures and switching to natural gas instead of fuel oil would reduce the overall pollutant emission rates. Furthermore, increasing the stack heights and release temperatures would result in greater initial plume dispersion and lower concentrations in the immediate vicinity of the refinery. The air pollution estimates made in this study suggest additional measures such as breathing masks given to nearby residents during high pollution days warrented.

Acknowledgments. We are very grateful to the Midland Refineries Company for their assistant to give us the necessary information related to the fuel consumed at production units, and thanks to the General Board for meteorological and seismic monitoring in Iraq for providing the meteorological observation data.

\section{References}

Abdul-Wahab, S.A., Al-Alawi, S.M., and El-Zawahry, A. (2002).
Patterns of $\mathrm{SO} 2$ emissions refinery case study. Journal Environmental Modeling and Software. 17, 563-570. https://doi.org/10.1 016/S1364-8152(02)00023-3

Ahrens, C.D., (2007). Essentials of Meteorology: An Invitation to the Atmosphere. 5th edition, Belmont. Thomson Learning Inc.

Dresser, A.L. and Huizer, R.D. (2011). CALPUFF and AERMOD model validation study in the near field Martins Creek revisited. Journal Air and Waste Management Association. 61,647-659. https://doi.org/10.3155/1047-3289.61.6.647

Elbir, T., (2003). Comparison of model predictions with the data of an urban air quality monitoring in Izmir, Turkey. Atmospheric Environment, 37, 2149-2157. https://doi.org/10.1016/S1352-231 0(03)00087-6

Gzar, H.A., (1998). Mathematical Modeling for Dispersion of Air Pollutants Emitted from Al-Daura Oil Refinery Stacks. Master thesis, college of Engineering, Baghdad University, Baghdad, Iraq.

Gzar, H.A. and Kseer, K.M. (2009). Pollutants emission and dispersion from flares a Gaussian case study in Iraq. Journal of Al-Nahrain University. 12(4), 38-57. https://doi.org/10.22401/JN US.12.4.06

Jeong, S.J. (2011). CALPUFF and AERMOD dispersion models for estimating odor emission from industrial complex area sources. Asian Journal of Atmospheric Environment. 5(1), 1-7. https://d oi.org/10.5572/ajae.2011.5.1.001

Lee, J.K., Kim, J.C., Lee, K.J., Belorid, M., Beeley, P.A., and Yun, J.I. (2014). Assessment of wind characteristics and atmospheric dispersion modeling of $137 \mathrm{Cs}$ on the Barakah NPP area in the UAE. Journal of Nuclear Engineering and Technology, 46(4), 557-568. https://doi.org/10.5516/NET.09.2014.029

Levy, J.I., Spengler, J.D., Hlinka, D., Sullivan, D., and Moon, D. (2002). Using CALPUFF to evaluate the impacts of power plant emissions in Illinois model sensitivity and implications. Atmospheric Environment. 36(6), 1063-1075. https://doi.org/10.1016/ S1352-2310(01)00493-9

Mehdizadeh, F. and Rifai, H.S. (2004). Modeling point source plumes at high latitudes using a modified Gaussian model. Atmospheric Environment. 38, 821-831. https://doi.org/10.1016/j.atmosenv.2003. 10.041

Oshan, R., Kumar, A., and Masuraha, A. (2006). Application of the USEPA's CALPUFF model to an urban area. Wiley Inter Scince: Environmental Progress, 25(1), 12-17. https://doi.org/10.1002/e p. 10132

Rood, A.S., (2014). Performance evaluation of AERMOD, CALPUFF, and legacy air dispersion models using the winter validation tracer study dataset. Atmospheric Environment, 89, 707-720. https://doi. org/ 10.1016/j.atmosenv.2014.02.054

Shubbar R.M., Salman, H.H., and Lee, D.I. (2016). Characteristics of climate variation indices in Iraq using a statistical factor analysis. RMets. International Journal of Climatology, 37, 918-927. https:// doi .org/10.1002/joc.4749

Scire, J.S., Strimaitis, D.G., and Yamartino, R.J. (2000). User Guide for the CALPUFF Dispersion Model, Version 5. Earth Tech, Inc. 196 Baker Avenue.

User guide EPA (Environmental Protection Agency), (1995). A User's Guide for the CALPUFF Dispersion Model, Office of Air Quality. Planning and Standards, 2-4. EPA-454/B-95-006. U.S.

Wark, K. and Warner, C.F. (1976). Air Pollution: Its Origin and Control, Harper and Row, New York.

Zakaria, S., Al-Ansari, N., and Knutsson, S. (2013). Historical and future climate change scenarios for temperature and rainfall for Iraq. Civil Engineering and Architecture. 7(12), 1574-1594. https:// doi.org/10.17265/1934-7359/2013.12.01 